\title{
EARNINGS ANNOUNCEMENTS AND COMPETING INFORMATION: THE INDONESIAN EVIDENCE
}

\author{
Dedhy Sulistiawan \\ Faculty of Business and Economics \\ Universitas Surabaya \\ (dedhy@ubaya.ac.id) \\ Jogiyanto Hartono \\ Eduardus Tandelilin \\ Supriyadi \\ Faculty of Economics and Business \\ Universitas Gadjah Mada
}

\begin{abstract}
The main purpose of this study is to provide empirical evidence of the relationship between investors' responses to two events, which are, (1) earnings anouncements, and (2) technical analysis signals, as competing information. This study is motivated by Francis, et al. (2002), whose study used stock analyst's recommendations as competing information in the U.S stock market. To extend that idea, this study uses technical analysis signals as competing information in the Indonesian stock market. Using Indonesian data from 2007-2012, this study shows that there are price reactions on the day of a technical analysis signal's release, which is prior to earnings announcements. It means that investors react to the emergence of competing information. Reactions on earnings announcements also produce a negative relationship with the reaction to a technical analysis signal before an earnings announcement. This study gives evidence about the importance of technical analysis as competing information to earnings announcements.
\end{abstract}

Keywords: competing information, earnings announcements, technical analysis, price reaction

\section{INTRODUCTION}

The main purpose of this study is to provide empirical evidence on the relationship between investors' responses to two events, which are (1) earnings anouncements, and (2) their competing information that is represented by a technical analysis signal before earnings anouncements. This study predicts that price reactions on a technical analysis signal before earnings announcements negatively affect the price reactions on earnings announcements.

The main idea of this study was motivated by Francis, et al. (2002) who conducted a study which used stock analyst's recommendations in the U.S. as competing information. While this study uses technical analysis signals in the Indonesian market as the competing information.
Analyst's recommendations were not considered in this study for several reasons, namely (1) the analysts also have bias in their estimation (DeBondt \& Thaler, 1990; Libby \& Tan, 1999), (2) the earnings quality in Indonesia is relatively low compared to other Asian countries (Fan \& Wong, 2002) and developed countries (Landsman, et al., 2012; Myring, 2006), and (3) an integrative analyst recommendation database is not available in Indonesia.

There are two main reasons why a technical analysis signal before an earnings announcement was selected as the competing information in Indonesia. First, technical analysis indicators generate good performance in developing markets, including Indonesia (McKenzie, 2007; Ahmed et al., 2000; Sulistiawan and Hartono, 
2014). Secondly, technical analysis is widely used by practitioners in the US (Flanegin \& Rudd, 2005) and also in Indonesia. Currently, there are many Indonesian investment communities/forums which discuss technical analysis signals, for example saham@yahoogroups. com that had over 11,000 members in early 2013.

This study expects a negative relationship between the reaction to a technical analysis signal before earnings announcements, and the reaction to the actual earnings announcement. To build the relationship between earnings anouncements and technical analysis as competing information, this research used market microstructure theory which predicts how information is incorporated into securities prices through trading activities (Meginson, 1997). The market microstructure theory which we used in this study is the price formation model. This model believes that informed investors and noise traders can affect the stock price. Users of technical analysis are considered to be informed investors, who trade based on price movements. They do not always trade based on fundamental information.

The remainder of the paper is organized as follows. The second section describes the previous published literature most closely related to the research question in this study. The third section describes our research methodology. The forth section presents the results of the tests, and the last section gives our conclusions from this study.

\section{LITERATURE REVIEW}

\section{Investors react to its competing information}

To discuss investors' reaction to a technical analysis signal before earnings announcement, this study used the market microstructure theory. This theory believes that there are two major parties in stock trading, informed investors and noise traders. This study assumes that informed investors react before earnings anouncements, while noise traders try to detect the informed investors reaction by observing price movements before earnings anouncements. Noise traders are investors who react to non-fundamental infor- mation. This idea is supported by Black (1986) who explains that noise traders reacts to noise as if noise is information. Shleifer \& Summers (1990) also argue that technical analysis users are a part of the noise traders grouping because they do not trade on fundamental information. It means that investors can react to non-fundamental information.

Accounting information competes with other information (Pinsker, 2007; Francis \& Schipper, 1999; Francis, et al., 2002). Beaver (1968) also explains that a companies' profit may indeed supply information to the market, but there are other resources available for investors that essentially contain the same information which is more timely. Francis, et al. (2002) used analyst recommendations as competing information to earnings announcements. This study uses technical analysis signals before earnings anouncements as competing information to earnings anouncements. The technical analysis signal is expected to detect investors' activities using a price chart. According to this idea, information after earnings announcements will be discounted because informed investors use it before earnings anouncements. Noise traders also try to use it for their own interests. The recognition of competing information discussed in Francis, et al. (2002) motivated this study to propose another competing information, which is technical analysis.

Technical analysis is selected because it is useful (Bessembinder \& Chan, 1995; Ahmed, et al., 2000; McKenzie, 2007; Fifield, et al., 2005; Milionis \& Papanagiotou, 2008). Sulistiawan \& Hartono's (2014) research also shows that a technical analysis signal before earnings announcements produces a good signal to generate a profitable return. Investors could not only react to fundamental information, but also to non-fundamental information (Black, 1986; Shleifer \& Summers, 1990). This study predicts the hypothesis as follow.

H1: Investors react to a technical analysis signal before earnings announcements.

This technical signal can be divided into buy and sell signals. A buy signal is an indicator that 
the stock price will go up. Conversely, a sell signal is an indicator that the stock price will fall. Based on that idea, $\mathrm{H} 1$ can be expanded into two hypotheses as follow.

H1a: Buy signals before an earnings announcement produces a positive reaction.

H1b: Sell signals before an earnings announcement produces a negative reaction.

\section{Competing information to earnings announcements}

There are several reasons to recognize why net income is not optimal. Beaver (1968) provides two important reasons. The first reason, earnings measurement errors are very large so that investors may use other information to estimate stock values. The second reason, there are many sources of information for investors other than earnings.

Earnings surprises are not the only information used by investors (Beaver, 1968). Porter (1992) argues that large numbers of analysts will reduce the usefulness of earnings announcements. It means that analysts' recommendations are competing information. This information is considered to be more timely. Francis, et al. (2002) also strongly argue for earnings anouncements to be competing information, meanwhile this is not supported by their data. Allen \& Ramanan (1990) also examined earnings surprises and insider trading before earnings announcements. Insider trading before earnings anouncements was considered as a signal for a stock trading transaction. In that study, when insiders sell (buy) before earnings announcements, price reactions on earnings announcements were negative (positive).

This study expands the idea of Francis, et al. (2002) and Allen \& Ramanan (1990) by using technical analysis signals. Technical analysis is used for two reasons. First, analysts also produce biased predictions as to future earnings. This idea is supported by the studies of DeBondt \& Thaler (1990) and Libby \& Tan (1999). Analysts predict the earnings and announce it to investors. This valuation will influence investors' decisions, who also tend to overreact. Secondly, technical analysis is competing information for accounting information, especially for short-term investing. Eitman \& Smith (1974) and Flanegin \& Rudd (2005) discuss the competition between fundamental and technical analysis. Francis, et al. (2002) in his article used analyst reports based on fundamental information. This study develops that idea by using the technical analysis signal.

Signals which appear before earnings anouncements also convey information. The information will drive price movements prior to earnings announcements. Informed investors activities before earnings announcements absorb the information content of earnings announcements. Competing information is already discussed in accounting literatures (Beaver, 1968; Ball \& Brown, 1968; Francis \& Schipper, 1999; Francis, et al., 2002; Porter, 1992), while empirical evidence from studies of Francis, et al. (2002) and Allen \& Ramanan (1990) could not demonstrate the existence of competing information. Any reaction on earnings announcement dates will have been absorbed by the reaction to the signal before earnings announcements. Based on those ideas, the second hypothesis is stated as follows.

$\mathrm{H} 2$ : There is a negative relationship between price reactions on technical analysis signal before earnings announcements and price reactions on earnings announcement dates.

\section{METHODOLOGY}

\section{Data and Sample}

This study uses Indonesian market data. This data is very contextual because the Indonesian stock market is a developing market. Previous studies show that Indonesian companies have lower earnings informativeness than other countries companies (Fan \& Wong, 2002; Landsman, et al., 2012), but stock prices produce a high quality technical analysis signal (McKenzie, 2007; Ahmed, et al., 2000). Regarding these ideas, this study uses Indonesian data, and technical analysis is determined to be competing information. 
This study uses all the companies listed on the Indonesia Stock Exchange (IDX). Earnings announcement dates are derived from the Indonesian Capital Market Library (ICAMEL) and financial data from OSIRIS. This study uses four variables, (1) price reaction on earnings announcement dates, (2) price reaction to technical analysis signal before earnings announcements, (3) earnings surprises, and (4) companies' size.

\section{Price reaction on earnings announcements} (AREA).

Price reaction is determined by the one day abnormal return on earnings announcement date. This study uses the market model to calculate expected return. Expected return is calculated using the model below.

$$
\mathrm{R}_{\mathrm{i}, \mathrm{t}}=\mathrm{a}_{\mathrm{i}}+\mathrm{b}_{\mathrm{i}} \cdot \mathrm{Rm}_{\mathrm{t}}+\varepsilon_{\mathrm{i}, \mathrm{t}}
$$

$\mathrm{R}_{\mathrm{i}, \mathrm{t}}$ is the daily return of stock $\mathrm{i}$ in year t. $\mathrm{Rm}_{\mathrm{t}}$ is the daily market return in year t. Using a one year estimation period, this regression generate $a_{i}$ and $b_{i}$ for each company/year. The duration ends on one-day before signal day before earnings announcements. The timing of this signal is determined by equations 4,5 , and 6. Based on equation 1, the value of $a_{i}$ and $b_{i}$ are used to calculate the expected return $\left(\mathrm{ER}_{\mathrm{i}, \mathrm{t}}\right)$.

$$
\begin{aligned}
& \mathrm{ER}_{\mathrm{i}, \mathrm{t}}=a_{i}+b_{i} \cdot \mathrm{Rm}_{\mathrm{t}} \\
& \mathrm{AREA}_{\mathrm{i}, \mathrm{t}}=\mathrm{Rt}_{\mathrm{i}, \mathrm{t}}-\mathrm{ER}_{\mathrm{i}, \mathrm{t}}
\end{aligned}
$$

AREA $_{i, t}$ is the abnormal return on earnings announcements date of company $i$ in year $t$. This variable is the dependent variable.

2. Price reaction to technical analysis signal before earnings announcements.

Price reaction to technical analysis signal (ARTAi,t) is also determined using equations 1,2 , and 3 . The difference is the timing. To determine the date of technical signal, this study uses SMA5. This indicator is selected because previous studies showed that this indicator generates a profitable return (Milionis \& Papanagiotou, 2008), especially before earnings announcements (Sulistiawan \& Hartono, 2014).

$$
\operatorname{SMA}(\mathrm{n})_{\mathrm{i}}=\left(\mathrm{P}_{\mathrm{n}, \mathrm{i}}+\mathrm{P}_{\mathrm{n}-1, \mathrm{i}}+\ldots+\mathrm{P}_{1, \mathrm{i}}\right) / \mathrm{n}
$$

$\mathrm{P}_{\mathrm{n}, \mathrm{i}}$ is the stock price $\mathrm{i}$ in previous $\mathrm{n}$ days, and $\mathrm{P}_{1, \mathrm{i}}$ is the stock price $\mathrm{i}$ one day before day 0 . The value of $\mathrm{n}$ is the period used in the indicator. Based on equation 4, technical analysis signal is determined by the crossing of the stock price chart and SMA5 indicator.

$$
\begin{aligned}
& \mathrm{S}_{\mathrm{B}, \mathrm{i}}=\left(\mathrm{P}_{0, \mathrm{i}}>\mathrm{SMAn}_{0, \mathrm{i}} \mid \mathrm{P}_{-1, \mathrm{i}}<\mathrm{SMAn}_{-1, \mathrm{i}}\right) \\
& \mathrm{S}_{\mathrm{S}, \mathrm{i}}=\left(\mathrm{P}_{0, \mathrm{i}}<\mathrm{SMAn}_{0, \mathrm{i}} \mid \mathrm{P}_{-1, \mathrm{i}}>\mathrm{SMAn}_{-1, \mathrm{i}}\right)
\end{aligned}
$$

$\mathrm{S}_{\mathrm{B}, \mathrm{i}}\left(\mathrm{SS}_{\mathrm{S}, \mathrm{i}}\right)$ is the buying (selling) signal of stock $i$ on a trading day. $\mathrm{P}_{0, \mathrm{i}}\left(\mathrm{P}_{-1, \mathrm{i}}\right)$ is the stock price of stock $i$ on 0 day (one-day before 0 day). $\operatorname{SMAn}_{0, \mathrm{i}}\left(\operatorname{SMAn}_{-1, \mathrm{i}}\right)$ is the value of SMAn on 0 day (one-day before 0 day). Signal day is a trading day before earnings announcements when $\mathrm{P}_{0, \mathrm{i}}>\mathrm{SMAn}_{0, \mathrm{i}}$ and $\mathrm{P}_{-1, \mathrm{i}}$ $<\mathrm{SMAn}_{-1, \mathrm{i}}$. Investors' reaction is measured by the one-day abnormal return on signal day that is determined by equations 1,2 , and 3 . This is the main independent variable of this study.

3. Earnings surprise

Good (bad) news is generated by positive (negative) annual earnings changes. This random-walk method is selected because retail investors react to annual earnings changes based on the random-walk model (Battacharya, 2001). Earnings surprise $\left(\mathrm{ES}_{\mathrm{i}, \mathrm{t}}\right)$ is measured by the annual net income difference scaled by the stock price in the sixdays before earnings announcements. The difference in annual net income is calculated by annual net income of year $t$ minus net annual income of year $\mathrm{t}-1$. In this study, $\mathrm{Es}_{\mathrm{i}, \mathrm{t}}$ is the controlling variable.

\section{Size}

In order to complete the test, the study also used the firm's size as a control variable. Firm size is represented by market capitalization $\left(\mathrm{Mcap}_{\mathrm{i}, \mathrm{t}}\right)$ which then uses $\operatorname{Ln}\left(\mathrm{MCap}_{\mathrm{i}, \mathrm{t}}\right)$. 


\section{Hypothesis testing}

Using the one-day abnormal return on technical signal this study expects that investors will react to the technical analysis signal before earnings announcements. For the purpose of $\mathrm{H} 1$, ARTA $_{i, t}$ that is generated by the selling signal is multiplied by minus one, because using that

$$
\text { H1: } \operatorname{ARTA}_{i, t}>0
$$

H1 may present the reaction, but splitting the sample based on buy and sell signals will generate a deeper analysis. This study also predicts that the reaction to a buy (sell) signal is positive (negative).

$$
\begin{aligned}
& \text { H1a: } \operatorname{ARTA}_{\mathrm{Bi}, \mathrm{t}}>0 \\
& \text { H1b: } \operatorname{ARTA}_{\mathrm{Si}, \mathrm{t}}<0
\end{aligned}
$$

Price reaction to a buy (sell) signal is notated by ARTA $_{B i, t}\left(\right.$ ARTA $\left._{\mathrm{Si}, t}\right)$. In $\mathrm{H} 1$ the abnormal return of the sell signal sample is multiplied by minus one. That procedure is not applied in H1b. Thus, a sell signal is expected to produce a negative reaction.

The second hypothesis predicts a negative relationship between the reaction to technical analysis signal before earnings announcements and reaction on earnings announcements. That hypothesis is examined by regression analysis as follow.

$$
\begin{aligned}
\operatorname{AREA}_{\mathrm{i}, \mathrm{t}}= & \mathrm{c} 1+\mathrm{c} 2 \cdot \mathrm{ARTA}_{\mathrm{i}, \mathrm{t}}+\mathrm{c} 3 \cdot \mathrm{ES}+ \\
& \mathrm{c} 4 \cdot \mathrm{Ln} \cdot \mathrm{Mcap}_{\mathrm{i}, \mathrm{t}-1}+\mathrm{e}_{\mathrm{i}, \mathrm{t}}
\end{aligned}
$$

$\mathrm{H} 2: \mathrm{c} 2<0$

\section{RESULTS AND ANALYSIS}

\section{Results}

Descriptive statistics of the abnormal return of earnings announcements are provided in Table 1. We estimate these statistics for both all samples (Panel A) and separately for the good and bad news samples (Panel B and C). Companies that report increasing (decreasing) net income are grouped in the good (bad) news samples. As shown in Panel A, the one-day abnormal return on earnings announcements is statistically insignificant. It can be understood because Panel 1 aggregates both the good and bad news, while Panel $\mathrm{B}$ and $\mathrm{C}$ show that earnings surprises are significantly positive (negative). It means that investors react to good (bad) news. In summary, Table 1 gives evidence that the market reacts to earnings announcements. The table above shows that earnings announcements produce a market reaction. Good (bad) news produces positive (negative) reactions. Although this evidence is not the main object of this study, these reports show that investors react in the same magnitude as the news.

Table 2 presents descriptive statistics of the abnormal return of technical analysis signal before earnings announcements. It uses SMA5 as the technical analysis indicator. Based on all sample data, the one-day abnormal return of technical signal is significantly positive. As shown in Table 2, both buy and sell signal sam-

\begin{tabular}{|c|c|c|c|c|c|c|}
\hline $\begin{array}{l}\text { Abnormal return on } \\
\text { Earnings Announcements }\end{array}$ & $\mathrm{N}$ & Min & Max & Mean & Std. Deviation & t-test \\
\hline \multicolumn{7}{|l|}{ Panel A } \\
\hline All samples & 738 & -0.74 & 0.25 & 0.0000 & 0.04629 & -0.022 \\
\hline \multicolumn{7}{|l|}{ Panel B } \\
\hline Good news sample & 510 & -0.15 & 0.25 & 0.0026 & 0.03796 & $1.560 *$ \\
\hline \multicolumn{7}{|l|}{ Panel C } \\
\hline Bad news sample & 227 & -0.74 & 0.20 & -0.0060 & 0.06076 & $-1.491 *$ \\
\hline
\end{tabular}
ples are combined. In all sample calculations, the abnormal return of sell signal sample is multiplied by minus 1 because buy and sell signal

Table 1. Abnormal return on earnings announcements 
samples have different directions. The result shows that $\mathrm{H} 1$ is supported.

In a buy signal sample, Table 2 presents a significant positive of abnormal return. It also means that H1a is supported. Thus buy signals produce a positive abnormal return. Conversely, the reaction to a sell signal sample is significantly negative. H1b is also supported. Those results give evidence that technical analysis signal before earnings announcements produce a market reaction.

Panel B of Table 2 shows the investors' reaction to a technical analysis signal before good news on earnings announcements. The good news sample produces a positive and significant reaction on signal day. This finding shows that in a good news sample, $\mathrm{H} 1$ is supported. To a buy signal before the good news sample, market reaction is also positive and significant. So, H1a is also supported. With a sell signal before a good news sample, investors reaction is negative and significant. These findings suggest that the market reacts before any good or bad news through the technical analysis signal.

Panel $\mathrm{C}$ of Table 2 also shows the same results. It means that using a good (bad) news sample, a buy (sell) signal produces an investors' reaction as predicted in $\mathrm{H} 1 \mathrm{a}$ and $\mathrm{H} 1 \mathrm{~b}$. Overall, Table 2 shows that H1, H1a and H1b are supported by the data.

These findings present the tendency for a reaction before any earnings announcement in anticipating formal news. This reaction is generated by the pre-announcement reaction because of speculation by investors, or a leakage of information. To improve the analysis, this study also uses SMA10 as a supplementary technical analysis signal. The results are presented in Table 3.

The findings presented in Table 3 show the same phenomena as in Table 2. In Panel A, (all samples), a buy (sell) signal sample produces a positive (negative) reaction. Both Panels B and $\mathrm{C}$ also give the same results. It means that when using SMA10, H1, H1a, and H1b are supported.

This study also predicts that there is a negative relationship between the price reaction on technical analysis signal before earnings announcements, and the price reaction on the earnings announcement date. This negative correlation indicates that the technical analysis

Table 2. Abnormal return on technical analysis signal before earnings announcements Abnormal return on SMA5 signal

\begin{tabular}{|c|c|c|c|c|c|c|}
\hline $\begin{array}{l}\text { Abnormal return on technical signal before } \\
\text { earnings announcements }\end{array}$ & $\mathrm{N}$ & Min & Max & Mean & $\begin{array}{c}\text { Std. } \\
\text { Deviation }\end{array}$ & t-statistics \\
\hline \multicolumn{7}{|l|}{ Panel A } \\
\hline All sample\# & 738 & -0.18 & 0.36 & 0.0252 & 0.03719 & $18.397 * * *$ \\
\hline Buy signal sample & 422 & -0.04 & 0.36 & 0.0253 & 0.03991 & $13.013 * * *$ \\
\hline Sell signal sample ${ }^{\wedge}$ & 316 & -0.26 & 0.18 & -0.0250 & 0.03326 & $-13.387 * * *$ \\
\hline \multicolumn{7}{|l|}{ Panel B } \\
\hline Good news sample\# & 510 & -0.16 & 0.36 & 0.0158 & 0.04185 & $8.506^{* * *}$ \\
\hline Buy signal on good news sample & 305 & -0.04 & 0.36 & 0.0250 & 0.04228 & $10.335^{* * *}$ \\
\hline Sell signal on good news sample ${ }^{\wedge}$ & 205 & -0.19 & 0.04 & -0.0247 & 0.02791 & $-12.652 * * *$ \\
\hline \multicolumn{7}{|l|}{ Panel C } \\
\hline Bad news sample\# & 227 & -0.18 & 0.26 & 0.0064 & 0.04502 & $2.145^{* * *}$ \\
\hline Buy signal on bad news sample & 116 & -0.03 & 0.15 & 0.0258 & 0.03322 & $8.376^{* * *}$ \\
\hline Sell signal on bad news sample ${ }^{\wedge}$ & 111 & -0.26 & 0.18 & -0.0258 & 0.04150 & $-6.539 * * *$ \\
\hline
\end{tabular}

**** significance level of $1 \%, 5 \%$, and $5 \%$ (one-tail test)

\# In this row, sell signal sample is multiplied by minus1. It is needed because buy and sell signal generate contrary magnitude. This procedure is not applied in sell signal sample ${ }^{\wedge}$.

This table uses abnormal return from trading strategy based on SMA5.

Companies that report decreasing (increasing) annual net income are identified as bad (good) news sample. 
signal before earnings announcements absorbs earnings announcement reactions. The results are presented in Table 4.

The results of the $\mathrm{H} 2$ test are presented in Table 4. The examination of $\mathrm{H} 2$ uses two different samples; the SMA5 sample and SMA10 sample. ARTA $A_{i, t}$ is determined by the abnormal return on the day SMA5 (SMA10) signal emerge for SMA5 sample (SMA10 sample). The equation in the third and fourth columns use earnings surprises $\left(\mathrm{UEP}_{\mathrm{i}, \mathrm{t}}\right)$ as the controlling variable. Based on all models and samples, the results show that there is a negative relationship between the abnormal return of

Table 3. Abnormal return on technical analysis signal before earnings announcements: Abnormal return based on SMA10

\begin{tabular}{lcccccc}
\hline $\begin{array}{l}\text { Abnormal return on technical signal before } \\
\text { earnings announcements }\end{array}$ & $\mathrm{N}$ & Min & Max & Mean & $\begin{array}{c}\text { Std. } \\
\text { Deviation }\end{array}$ & t-statistics \\
\hline Panel A & & & & & & \\
$\quad$ All samples\# & 746 & -0.15 & 0.37 & 0.0271 & 0.03623 & $20.407^{* * *}$ \\
$\quad$ Buy signal sample & 446 & -0.15 & 0.28 & 0.0277 & 0.03913 & $14.949^{* * *}$ \\
$\quad$ Sell signal sample & 300 & -0.37 & 0.03 & -0.0261 & 0.03146 & $-14.384^{* * *}$ \\
Panel B & & & & & & \\
$\quad$ Good news sample\# & 514 & -0.15 & 0.25 & 0.0255 & 0.03294 & $17.545^{* * *}$ \\
$\quad$ Buy signal before good news sample & 319 & -0.15 & 0.25 & 0.0258 & 0.03633 & $12.727^{* * *}$ \\
$\quad$ Sell signal before good news sample^ & 195 & -0.19 & 0.03 & -0.0250 & 0.02646 & $-13.184^{* * *}$ \\
Panel C & & & & & & \\
$\quad$ Bad news sample\# & 231 & -0.03 & 0.37 & 0.0305 & 0.04258 & $10.896^{* * *}$ \\
$\quad$ Buy signal before bad news sample & 126 & -0.03 & 0.28 & 0.0324 & 0.04530 & $8.030^{* * *}$ \\
$\quad$ Sell signal before bad news sample^ & 105 & -0.37 & 0.01 & -0.0283 & 0.03915 & $-7.396^{* * *}$ \\
\hline
\end{tabular}

***,**,* significance level of $1 \%, 5 \%$, and $5 \%$ (one-tail test).

\# In this sample, sell signal sample is multiplied by minus1. It is needed because buy and sell signal generate contrary magnitude. This procedure is not applied in sell signal sample ${ }^{\wedge}$.

This table uses abnormal return from trading strategy based on SMA10.

Companies that report decreasing (increasing) annual net income are identified as bad (good) news sample.

Table 4. Test of $\mathrm{H} 2$

\begin{tabular}{lcccc}
\hline Dependent variable AREA & $\begin{array}{c}\text { SMA5 sample } \\
(1)\end{array}$ & $\begin{array}{c}\text { SMA10 sample } \\
(2)\end{array}$ & $\begin{array}{c}\text { SMA5 sample } \\
(3)\end{array}$ & $\begin{array}{c}\text { SMA10 sample } \\
(4)\end{array}$ \\
\hline Intercept & 0.000312 & 0.001133 & 0.000497 & 0.001289 \\
(t-statistics) & $(0.06620)$ & $(0.242684)$ & $(0.106723)$ & $(0.278589)$ \\
ARTA $_{\mathrm{i}, \mathrm{t}}$ & -0.078997 & -0.08513 & -0.075940 & -0.083475 \\
(t-statistics) & $(-2.073709)^{* *}$ & $(-2.25085)^{* *}$ & $(-2.01212)^{* *}$ & $(-2.228306)^{* *}$ \\
LnMcap $_{\mathrm{i}, \mathrm{t}-1}$ & -0.000009 & -0.00015 & -0.000053 & -0.000185 \\
(t-statistics) & $(-0.012153)$ & $(-0.18218)$ & $(-0.066191)$ & $(-0.231708)$ \\
UEP $_{\mathrm{i}, \mathrm{t}}$ & & & 0.000010 & 0.000010 \\
(t-statistics) & & & $(3.891192)^{* * *}$ & $(3.921872)^{* * *}$ \\
Adjusted $\mathrm{R}^{2}$ & & & 0.022 & 0.023 \\
(n) & 0.003134 & 0.004141 & $(738)$ & $(746)$
\end{tabular}

Abnormal return on technical analysis signal before earnings announcements is independent variable $\left(\mathrm{ARTA}_{\mathrm{i}, \mathrm{t}}\right)$. Market capitalization $\left(\operatorname{LnMcap}_{\mathrm{i}, \mathrm{t}-1}\right)$ and earnings surprise $\left(\mathrm{UEP}_{\mathrm{i}, \mathrm{t}}\right)$ are control variables. Abnormal return on earnings announcement dates is dependent variable $\left(\mathrm{AREA}_{\mathrm{i}, \mathrm{t}}\right) . * * *, * *, *$ indicate that the test is significant at $1 \%, 5 \%$, and $10 \%$. (one-tail test). 
technical analysis signal before earnings announcements and the abnormal return on earnings announcements. Thus, $\mathrm{H} 2$ is supported.

The regression coefficient of ARTAi,t is 0.078997 for the SMA5 sample. In the SMA10 sample, the regression coefficient is -0.08513 . A low $\mathrm{R}^{2}$ in both the SMA5 (1) and SMA10 samples (2) are because earnings surprise is not included. After adding the controlling earnings surprise into the equations, the adjusted $\mathrm{R}^{2}$ increases from $0.3 \%$ to $2.2 \%$ in the SMA5 sample and from $0.4 \%$ to $2.3 \%$ in the SMA 10 sample.

The regression equation is estimated after considering the classical assumptions of multiple regressions: Durbin Watson multicollinearity test, heteroscedasticity test and auto correlation test. Jarque-Berra and Kolmogorov-Smirnov tests show that the residual distribution is not normal, meanwhile this study used a central limit theorem assumption in which sampling distribution will be normal when the sample size is a large enough random (Neter, et al., 1992). More than one hundred samples are described so that sampling distribution is normal. To overcome this problem, alternative procedures are used by using a random portfolio sample. The procedure is presented in the supplementary analysis.
The results presented in Table 4 are not grouped by good and bad news from earnings surprise. To generate deeper analysis, this study also analyzes $\mathrm{H} 2$ based on the sign of surprise. The results are presented in Table 5 .

Using a negative SMA5 sample in a positive (negative) earnings surprise condition, $\mathrm{H} 2$ is (not) supported. It means that the technical signal absorbs the price reaction on earnings announcements when anticipating good news. Using the SMA10 sample, both negative and positive conditions produce the negative relationship between the abnormal return on technical signal before earnings announcements and the abnormal return on earnings announcements. Overall, this study still provides evidence that $\mathrm{H} 2$ is supported.

\section{Supplementary Analysis}

The examination of the relationship between investors' reaction to a technical analysis signal and the market reaction on earnings announcements indicates that stock price movements before the earnings announcements absorb the price reaction after earnings announcements. To support this argument, this study also examined the effect of price reaction prior and after the earnings announcement. The abnormal return $\mathrm{x}$ days after earnings announcements is the

Table 5. The test of $\mathrm{H} 2$ based on positive (negative) earnings surprise

\begin{tabular}{|c|c|c|c|c|}
\hline \multirow[b]{2}{*}{$\begin{array}{l}\text { Dependent } \\
\text { variable } \mathrm{AREA}_{i}\end{array}$} & \multicolumn{2}{|c|}{ SMA5 sample } & \multicolumn{2}{|c|}{ SMA10 sample } \\
\hline & $\begin{array}{c}\text { Negative earnings } \\
\text { surprise }\end{array}$ & $\begin{array}{l}\text { Positive earnings } \\
\text { surprise }\end{array}$ & $\begin{array}{c}\text { Negative earnings } \\
\text { surprise }\end{array}$ & $\begin{array}{c}\text { Positive earnings } \\
\text { surprise }\end{array}$ \\
\hline $\begin{array}{l}\text { Intercept } \\
\text { (t-statistics) }\end{array}$ & $\begin{array}{c}-0.008993 \\
(-0.877307)\end{array}$ & $\begin{array}{c}0.007^{*} \\
(1.4101465)\end{array}$ & $\begin{array}{c}-0.007783 \\
(-0.744997)\end{array}$ & $\begin{array}{c}0.008009^{* *} \\
(1.689000)\end{array}$ \\
\hline $\begin{array}{l}\text { ARTA }_{i, t} \\
\text { (t-statistics) }\end{array}$ & $\begin{array}{c}-0.050099 \\
(-0.576762)\end{array}$ & $\begin{array}{c}-0.0862236^{* *} \\
(-2.3054088)\end{array}$ & $\begin{array}{l}-0.104673^{*} \\
(-1.366988)\end{array}$ & $\begin{array}{c}-0.068497 * * \\
(-1.702041)\end{array}$ \\
\hline $\begin{array}{l}\text { LnMcap }_{\mathrm{i}, \mathrm{t}-1} \\
\text { (t-statistics) }\end{array}$ & $\begin{array}{c}0.000705 \\
0.360413)\end{array}$ & $\begin{array}{c}-0.0007645 \\
(-0.9566711)\end{array}$ & $\begin{array}{c}0.000559 \\
(0.280674)\end{array}$ & $\begin{array}{c}-0.000954 \\
(-1.203935)\end{array}$ \\
\hline $\begin{array}{l}\mathrm{UEP}_{\mathrm{i}, \mathrm{t}} \\
\text { (t-statistics) }\end{array}$ & $\begin{array}{l}0.00001 * * \\
(1.795791)\end{array}$ & $\begin{array}{c}0.000009 * * * \\
(3.4561857)\end{array}$ & $\begin{array}{c}0.000009 * * \\
(1.695424)\end{array}$ & $\begin{array}{c}0.000009 * * * \\
(3.439325)\end{array}$ \\
\hline $\begin{array}{l}\text { Adjusted } \mathrm{R}^{2} \\
\text { (n) }\end{array}$ & $\begin{array}{l}0.004 \\
(226)\end{array}$ & $\begin{array}{l}0.029 \\
(510)\end{array}$ & $\begin{array}{l}0.009 \\
(231)\end{array}$ & $\begin{array}{l}0.025 \\
(514)\end{array}$ \\
\hline
\end{tabular}

Abnormal return on technical analysis signal before earnings announcements is independent variable $\left(\right.$ ARTA $\left._{i, t}\right)$. Market capitalization $\left(\operatorname{LnMcap}_{i, t-1}\right)$ and earnings surprise $\left(\mathrm{UEP}_{\mathrm{i}, \mathrm{t}}\right)$ are control variables. Abnormal return on earnings announcement dates is dependent variable $\left(\mathrm{AREA}_{\mathrm{i}, \mathrm{t}}\right) . * * *, * *, *$ indicate that the test is significant at $1 \%, 5 \%$, and $10 \%$. (one-tail test). 
dependent variable $\left(\mathrm{Arta}_{\mathrm{i}, \mathrm{t}}\right)$. The main independent variable is the abnormal return $\mathrm{x}$-days before earnings announcements $\left(\mathrm{Artb}_{\mathrm{i}, \mathrm{t}}\right)$. The abnormal return is calculated using a market model as in equations 1,2 , and 3 . The estimation also uses size as a control variable. In this supplementary analysis, this study used $\ln$ total asset $\left(\operatorname{LnAsset}_{\mathrm{i}, \mathrm{t}-\mathrm{l}}\right)$. The test also used several random portfolio samples. This study selected one hundred data in random for each process and the average of random data is determined. This process is repeated one hundred times to form the random portfolio samples. The results are presented in Table 6 .

In Table 6, the coefficients of return before earnings announcement present a negative value. Those are statistically significant. It means that the reaction before earnings announcements absorb the price reaction after earnings announcements. The estimation in Panel A contains a heteroskedasticity problem. In Panel B, the regression estimation is presented after corrected variance using White's test.

The regression estimations indicate a negative relationship between the price reactions before and after earnings announcements. These findings show return reversal phenomena on earnings announcement dates.

\section{Analysis}

The main purpose of this study was to examine the relationship between investors' reactions to a technical analysis signal prior to an earnings announcement and investors' reactions to the earnings announcement. Using market microstructure theory, this study recognizes the existence of informed investors and noise traders. Informed investors react before earnings announcements, while noise traders try to detect informed investors reactions using price movements before earnings anouncements. Noise traders react to noise as if noise is

Table 6. Price reaction before and after earnings announcements: Random portfolio sample

\begin{tabular}{|c|c|c|c|c|c|}
\hline No & $\operatorname{Arta}_{\mathrm{i}, \mathrm{t}}$ & $\begin{array}{l}\text { Intercept } \\
\text { (t-statistics) }\end{array}$ & $\begin{array}{l}\text { Artb }_{\mathrm{i}, \mathrm{t}} \\
\text { (t-statistics) }\end{array}$ & $\begin{array}{l}\text { LnAsset }_{\mathrm{i},-1} \\
\text { (t-statistics) }\end{array}$ & $\begin{array}{l}\text { Adjusted } \\
\mathrm{R}^{2}\end{array}$ \\
\hline \multicolumn{6}{|c|}{ Panel A: Regression analysis before corrected variance using White method. } \\
\hline 1 & $\begin{array}{l}5 \text { days before and after earnings } \\
\text { announcements }\end{array}$ & $\begin{array}{l}0.109 \\
(1.756)^{*}\end{array}$ & $\begin{array}{l}-0.248 \\
(-1.621)^{*}\end{array}$ & $\begin{array}{l}-0.007 \\
(-1.24)\end{array}$ & 0.03 \\
\hline 2 & $\begin{array}{l}4 \text { days before and after earnings } \\
\text { announcements }\end{array}$ & $\begin{array}{l}0.108 \\
(0.144)\end{array}$ & $\begin{array}{l}-0.449 \\
(2.137)^{* * * *}\end{array}$ & $\begin{array}{l}-0.007 \\
(-1.276)\end{array}$ & 0.044 \\
\hline 3 & $\begin{array}{l}3 \text { days before and after earnings } \\
\text { announcements }\end{array}$ & $\begin{array}{l}0.045 \\
(0.839)\end{array}$ & $\begin{array}{l}-0.937 \\
(-5.757)^{* * *}\end{array}$ & $\begin{array}{l}-0.003 \\
(-0.671)\end{array}$ & 0.25 \\
\hline 4 & $\begin{array}{l}2 \text { days before and after earnings } \\
\text { announcements }\end{array}$ & $\begin{array}{l}0.0001 \\
(0.995)\end{array}$ & $\begin{array}{l}-1.003 \\
(-6.510)^{* * *}\end{array}$ & $\begin{array}{l}0.0001 \\
(-0.937)\end{array}$ & 0.294 \\
\hline 5 & $\begin{array}{l}1 \text { days before and after earnings } \\
\text { announcements }\end{array}$ & $\begin{array}{l}-0.006 \\
(0.152)\end{array}$ & $\begin{array}{l}-0.927 \\
(-6.274) * * *\end{array}$ & $\begin{array}{l}0.0007 \\
(0.239)\end{array}$ & 0.279 \\
\hline \multicolumn{6}{|c|}{ Panel B: Regression analysis after corrected variance using White method. } \\
\hline 1 & $\begin{array}{l}5 \text { days before and after earnings } \\
\text { announcements }\end{array}$ & $\begin{array}{l}0.108 \\
(1.734)^{*}\end{array}$ & $\begin{array}{l}-0.248 \\
(-1.354)^{*}\end{array}$ & $\begin{array}{l}-0.006 \\
(-1.54)^{*}\end{array}$ & 0.03 \\
\hline 2 & $\begin{array}{l}4 \text { days before and after earnings } \\
\text { announcements }\end{array}$ & $\begin{array}{l}0.107 \\
(1.316)\end{array}$ & $\begin{array}{l}-0.449 \\
(-1.769) * *\end{array}$ & $\begin{array}{l}-0.006 \\
(-1.141)\end{array}$ & 0.043 \\
\hline 3 & $\begin{array}{l}3 \text { days before and after earnings } \\
\text { announcements }\end{array}$ & $\begin{array}{l}0.044 \\
(0.934)\end{array}$ & $\begin{array}{l}-0.937 \\
(-3.808) * * *\end{array}$ & $\begin{array}{l}-0.002 \\
(-0.747)\end{array}$ & 0.25 \\
\hline 4 & $\begin{array}{l}2 \text { days before and after earnings } \\
\text { announcements }\end{array}$ & $\begin{array}{l}0.005 \\
(0.184)\end{array}$ & $\begin{array}{l}-0.414 \\
(-2.151)^{* * *}\end{array}$ & $\begin{array}{l}0.0008 \\
(-0.334)\end{array}$ & 0.166 \\
\hline 5 & $\begin{array}{l}1 \text { days before and after earnings } \\
\text { announcements }\end{array}$ & $\begin{array}{l}-0.006 \\
(0.149)\end{array}$ & $\begin{array}{l}-0.927 \\
(-3.592)^{* * *}\end{array}$ & $\begin{array}{l}0.0007 \\
(0.233)\end{array}$ & 0.279 \\
\hline
\end{tabular}

The independent variable is cumulative abnormal return $\mathrm{x}$ days before earnings announcements $\left(\mathrm{ARtb} \mathrm{b}_{\mathrm{i}, \mathrm{t}}\right)$. Size $\left(\right.$ LnAsset $\left._{i, t-1}\right)$ is control variable. The dependent variable is cumulative abnormal return $\mathrm{x}$ days after earnings announcements $\left(\mathrm{ARta}_{\mathrm{i}, \mathrm{t}}\right)$. $* * *, * *, *$ significant at $1 \%, 5 \%$, dan $10 \%$. 
information (Black, 1986). Shleifer \& Summers (1990) also state that technical analysis users are a part of the noise traders because they do not trade on fundamental information.

Using an abnormal return on the day of the technical signal prior to earnings announcements, this study gives evidence about the market reaction to a technical analysis signal. Buy and sell signals before earnings announcements evoke investors' reactions. Moreover, investors also give smart reactions. Buy signals generate a positive abnormal return, and vice versa. These results are generated after considering good and bad news cases.

Using competing information to the earnings announcement idea, this study presents the absorption of information prior to earnings announcements which makes a negative relationship between returns from technical analysis prior to earnings announcements, and return on earnings announcements. Using both the SMA5 and SMA10 signals, those samples show the same phenomena that are represented by negative coefficients of regression estimates. This test complements the study of Francis, et al. (2002) which seeked to demonstrate the existence of competing information. These studies generally show a negative relationship between the return of technical analysis signals prior to the earnings announcements and the earnings announcement event returns.

To complete the discussion, this study also tested the relationship between the returns before earnings announcements and earnings announcement returns. The results statistically show significant negative coefficients. These findings indicate a shift from a reaction after earnings announcements to a reaction before earnings announcements. Based on that evidence, this study concludes that investors react before earnings announcements.

\section{CONCLUSIONS}

Differing from previous competing research (Francis, et al., 2002), this research develops a study by using a technical analysis signal. Based on that idea, this study focuses on the role of the technical analysis signal before earnings announcements as competing information. The study of Sulistiawan \& Hartono (2014) concluded that technical analysis signals before earnings announcements generally are more reliable than the first signal after earnings announcements.

Based on our hypothesis testing supported by relevant theory, this study concludes two important things. Firstly, a technical analysis signal before earnings announcements produces a significant abnormal return. Buy (sell) signals produce positive (negative) abnormal returns on the technical analysis signal dates. Secondly, there is a negative relationship between the price reaction on a technical analysis signal before earnings announcements, and the price reaction on earnings announcement dates. This phenomenon shows that the technical analysis signal before earnings announcements is a significant competing information for earnings announcements.

This study is expected to benefit other competing information studies. Francis, et al. (2002) in his article, used an analyst recommendation; our study develops it by using a technical analysis signal. This study also makes an important contribution in connecting technical analysis research and earnings announcements research. One final contribution is for the practical implications. This study offers contextual trading strategies for stock investors about how to trade using competing information around earnings announcements.

This study uses annual earnings announcements. The use of quarterly earnings announcements may also expand this idea. From the competing information perspective, this study needs to be expanded with more independent variables, for example foreign buy/sell on the emergence day of technical analysis signals or on earnings announcements.

\section{REFERENCES}

Ahmed, P., K. Beck, and E. Goldreyer, 2000."Can Moving Average Technical Trading Strategies Help in Volatile and Declining Markets? A Study of Some Emerging Asian Markets". Managerial Finance,26, 49-62. 
Allen, S., and R. Ramanan, 1990. "Earnings Surprises and Prior Insider Trading: Test of Joint Informativeness". Contemporary Accounting Research, 6, 518-543.

Ball, R., and P. Brown, 1968."An Empirical Evaluation of Accounting Income Numbers". Journal of Accounting Research,6, 159-178.

Battacharya. N., 2001. "Investors' Trade Size and Trading Responses Around Earnings Announcements: An Empirical Investigation". Accounting Review, 76, 221-244.

Beaver. W., 1968. "The Information Content of Annual Earnings Announcements". Journal of Accounting Research,6, 67-92.

Bessembinder, H., and K. Chan, 1995. "The Profitability of Trading Rules in the Asian Stock Markets". Pasific-Basin Finance Journal, 3, 257-284.

Black, Fischer, 1986. "Noise". Journal of Finance, 41, 529-543.

Brock,W.,J. Lakonishok, and B. LeBaron, 1992. "Simple Technical Trading Rules and The Stochastic Properties of Stock Returns". Journal of Finance.47, 1731-1764.

DeBondt, W.F.M., and R.H. Thaler, 1990. "Do Security Analysis Overreact?”. American Economic Review, 80, 52-57.

Eiteman, D.K., and K.V. Smith, 1974. "A Portfolio Analysis of Teaching of Investments. Journal of Financial and Quantitative Analysis, 9, 771-780.

Fan, Joseph P.H., and T.J. Wong, 2002. "Corporate Ownership Structure and the Informativeness of Accounting Earnings In East Asia". Journal of Accounting and Economics,33, 401-425.

Fifield, S.G.M., D.M. Power, and C.D. Sinclair, 2005. "An Analysis of Trading Strategies in Eleven European Stock Markets". The European Journal of Finance 11: 531-548.

Flanegin, F.R., and D.P. Rudd, 2005. "Should Investments Professors Join the Crowd". Managerial Finance,31, 28-37.

Francis, J., and K. Schipper, 1999."Have Financial Statements Lost Their Relevance?". Journal of AccountingResearch,37, 319-352.

Francis, J., K. Schipper., and L. Vincent, 2002. "Earnings Announcements and Competing
Information". Journal of Accounting and Economics, 33, 313-342.

Landsman, W.R., E.L. Maydew, and J.R. Thornock, 2012. "The Information Content Of Annual Earnings Announcements And Mandatory Adoption Of IFRS". Journal of Accounting and Economics,53, 34-54.

Libby, R., and H. Tan, 1999. "Analysts' reaction to warnings of negative earnings surprises". Journal of Accounting Research,37, 415435.

McKenzie, M.D., 2007. "Technical trading rules in emerging markets and the 1997 Asian Currency Crises". Emerging Markets Finance and Trade, 43, 46-73.

Meginson, William L., 1997. Corporate Finance Theory. Reading:Addison Wesley.

Milionis, A.E., and E. Papanagiotou, 2008. "On The Use of Moving Average Trading Rule Test for Weak Form Efficiency in Capital Markets". Review of Banking, Finance and Monetary Economics, 2, 181-201.

Mrying, Mark, 2006. "The Relationship Between Returns and Unexpected earnings: A Global Analysis by Accounting Regimes". Journal of International Accounting. Auditing and Taxation, 15, 92108.

Netter, John, W. Wasserman, and G.A. Whitmore, 1992. Applied Statistics, $4^{\text {th }}$ ed. Boston, United States: Allyn and Baccon

Pinsker, R., 2007. "Long Series of Information and Nonprofessional Investors' Belief Revision". Behavioral Research in Accounting,19,197-214.

Porter, G., 1992. "Accounting Earnings Announcements, Institutional Investor Concentration, and Common Stock Returns". Journal of Accounting Research, 30, 146155.

Shleifer, A. and L.H. Summers, 1990. "The Noise Trader Approach to Finance". Journal of Economic Perspectives,4, 19-33.

Sulistiawan D., and J. Hartono, 2014. "Can Technical Analysis Signals Detect Price Reactions Around Earnings Announcements?: Evidence From Indonesia". International Journal of Business and Finance Research (forthcoming). 
Sweeney, R.J., 1988. "Some New Filter Rule Tests: Methods and Results". Journal of Financial and Quantitative Analysis, 23, 285-300.

Wong, W., M. Manzur, and B. Chew, 2003. "How Rewarding is Technical Analysis? Evidence from Singapore Stock Market". Applied Financial Economics, 13, 543-551. 